\title{
Design Of Geographic Information Systems Monitoring Waqf At The Cikupa Sub-District Religious Affairs Office
}

\author{
Harfizar $^{1}$, Mulyati ${ }^{2}$, Mohamad Ali Fikri ${ }^{3}$ \\ ${ }^{1,2,3}$ Raharja University, Jl. Jendral Sudirman No.40 Modernland, Cikokol, Tangerang \\ e-mail: harfizar@raharia.info, mulyati@raharia.info, ali.fikri@raharia.info
}

\begin{abstract}
Geographic Information System Technology (GIS) / Geographic Information System (GIS) is a technological information system regarding geography that is very developed until now. GIS can be used by various fields of science, work, and events. Along with the advancement of information technology in the modern era, government services to the public must adapt to the demands of the times. The Office of Religious Affairs is an office that carries out part of the duties of the Indonesian Ministry of Religion in regencies and municipalities in the field of Islamic religious affairs within the sub-district. The purpose of this study is to improve the management of waqf property by displaying the geographical locations of waqf land so that it is easier to monitor waqf so that its utilization can be maximized through the geographical information system at the Office of Religious Affairs of the Cikupa District. Endowments are assets of the people who must be saved, managed well, and developed for useful purposes. The system analysis method used is PIECES which consists of Performance, Information, Economy, Control, Efficiency and Service. Unified modeling Language $(U M L)$ as a tool to analyze system procedures that are running. With geographic information system monitoring waqf land can display the location of waqf land located in Cikupa District by displaying through digital maps contained in geographic information systems.
\end{abstract}

Keywords: Systems, Monitoring, Endowments, Geographical.

\section{Introduction}

Geographic Information System Technology (GIS) / Georaphic Information System (GIS) is a technological information system regarding geography that is very developed until now. According to Putra \& Kadris in the journal. TEKNOIF Journal. Vol. 4 No. 2 (2016: 77) says that "Geographic Information Systems (GIS) is a computer-based information system, designed to work using data that has spatial information (spatial references) [8]. This system captures, checks, integrates, manipulates, analyzes and displays data that spatially reflects the condition of the earth. "GIS has a very good ability in visualizing spatial data and its attributes, modifying shapes, colors, sizes, and symbols. GIS can be used by various fields of science, work, and events.

According to Law No. 41 Article 1 of 2004 referred to "Waqf is a legal act of wakif (the party that carries out waqf) to separate and / or surrender a portion of his property to be used forever or for a certain period of time in accordance with his interests for the purposes of worship and / or general welfare according to sharia" [9]. Waqf objects that can be represented are movable and immovable objects that are owned immovably in the form of land, property rights to the house, atbolo ayao (the best) in the form of money. In Law Number 41 of 2004 concerning Waqf, the elements of waqf are six, namely wakif (the party who confers his property), Nazhir (manager of waqf assets), property of waqf, allocation, waqf contract, and period of waqf [10]. 
Along with the advancement of information technology in the modern era, government services to the public must adapt to the demands of the times. Creativity and innovation as a form of service to society is absolute and very much needed and one of them is by providing information technology-based services.

Geographical information system monitoring waqf land assets can be seen as a strategy, solution and effort to support, help improve management of waqf land assets in the long term and provide competitive advantages and advantages as an integrated system that is expected to minimize the loss of a number of waqf assets.

Office of Religious Affairs Cikupa District is a government agency under the auspices of the Ministry of Religion of Tangerang Regency which has an area of $43,407 \mathrm{~km} 2$, a population of 224,678 people, there are 12 villages and 2 kelurahan. The Office of Religious Affairs in Cikupa Subdistrict is engaged in Munakahat, Perwakafan, Zakat, Social Worship, etc. services, fostering Semi-Official Agencies / Agencies such as MUI, BAZ, BP4, LPTQ and Cross-Sectoral tasks in the District [11]. At the Office of Religious Affairs Cikupa Subdistrict in the system of searching for waqf land assets still uses physical evidence in a room, so if you need the desired data, you have to search one by one in the archive room.

Based on the results of these studies there are several main issues in the process of mapping waqf land at the Office of Religious Affairs of Cikupa District, namely:

1) What is the current process of the perwakafan system at the Office of Religious Affairs of Cikupa District?

2) How to make a geographic information system design for monitoring waqf land assets at the Cikupa District Religious Affairs Office?

3) How to process geographic information systems for monitoring waqf land assets at the Cikupa District Religious Affairs Office?

\section{Research Method}

In carrying out the design on a system there are several important things that must be considered, including the existence of research methods to solve various formulation of the problems that exist in the stages of this research. In writing this journal using the 4 stages used in the research method are as follows:

\section{A. Observation}

In this method the author made an observation by coming to the Office of Religious Affairs of Cikupa District. In this way the writer can observe directly how the process of management of waqf land that occurred at the Office of Religious Affairs Cikupa District on Jalan Raya Serang KM. 13.5 Kp. Cirewed, Sukadamai Village, Cikupa District, Tangerang Regency.

\section{B. Literature Review}

According to Azizah, et al in the Journal of SENSI Vol. 3 No. 2 (2017: 185), "Literature is literature or literature, while a review is an act of reviewing, re-examining something that has been done before so that in the literature review it can be concluded as an act of checking and reviewing a literature". In this Literature Review method the author studies, collects, and summarizes from several sources such as journals, theses and several reference books related to research to obtain data and information needed as the reference material for the author in completing journal writing [7]. The following is the research that has been carried out and has a correlation that is in line with the research that will be discussed in this journal, including: 
1) Research conducted by Amiq Fahmi and Egi Sugiarto in 2015. This research is entitled "Asset Waqf Management Geographic Information System Application". This research is about developing a geographic asset management information application system in Semarang City that can be used to store, process, control waqf assets in order to save waqf assets to the point of endowments and produce good information in the form of reports, documents, graphics, map images and other outputs which is relevant. Endowments are assets of the people who must be saved, managed well, and developed for useful purposes [1].

2) Research conducted by Amiq Fahmi and Edi Sugiarto in 2016. This research is entitled "Geographic Information System for Management and Monitoring of Distribution of Endowments Assets". This research is about improving the management of waqf assets (assets) in the long term at the Semarang Ministry of Religion Office. Strategic planning of waqf asset management information system resources is used to meet the functional needs of Syari'ah Organizers based on the objectives to be achieved and the information resources needed. System planning includes goals, constraints and design strategies to meet the needs of all levels of the Shari'ah Organizing organization [2].

3) Research conducted by Sutejo in 2016. This research is entitled "UML Modeling of Pekanbaru City Traditional Market Geographical Information System". This study of Geographic Information Systems (GIS) is designed to collect data, store and change data, and analyze objects and geographic data that are important for analysis. GIS presented with web-based design can also be used as a tool to provide information to the general public. The results of the research with UML modeling (Unified Modeling Language) are very helpful in the process of designing a traditional market geographic information system and the application of this web-based traditional market geographic information system can be used as a means of market information, especially for prospective traders who want to trade in one market traditional in the city of Pekanbaru [3].

4) Research conducted by Ummi Athiyyah Yuniarti, Bambang Sudarsono and Arwan Putra Wijaya in 2014. This research is entitled "Application of Web-Based Geographical Information System for the spread of dengue hemorrhagic fever (Case Study: Kudus Regency)". This research is about delivering information on the spread of the disease and helping to analyze the condition of an area against the disease to determine what actions should be taken to deal with the disease using the Geographic Information System (GIS). The existence of a Geographic Information System (GIS) is expected to be able to provide an overview of the spread of Dengue Hemorrhagic Fever in Kudus Regency, because Dengue Hemorrhagic Fever (DHF) is a disease that is quite common in Indonesia [4].

5) Research in the CERITA Journal Vol. 5 No. 1 conducted by Chaidir Kurnia Thoullah, Agnia Bilqisti, and Dhimas Alifiyanto in 2019 with the title "Designing Geographic Information Systems (GIS) as Information Media for Web-Based Employee Work in South Tangerang 6 Vocational Schools". This research is about a web-based geographic information system (GIS) that provides information about the location of the company in the city of Tangerang. In location search certainly requires a location or a position known as geographic information. Geographical information that is most widely used by the public at this time is the Google Maps application [5].

Based on the 5 Literature Review described above, it can be concluded that geographic information systems are currently experiencing very rapid development, such as web-based geographic information systems which can provide a more accurate location in the mapping process, and can facilitate location search or later data.

\section{Analysis}

In this analysis method the author studies and analyzes the system of representatives who are currently running at the Office of Religious Affairs in Cikupa District. From the results of the analysis obtained by the author using PIECES Analysis, namely (Performance, Information, 
Economy, Control, Efficiency and Service). According to Yuli Asbar and Mochamad Ari Saptari (2017: 40), "PIECES Analysis (Performance, Information, Economy, Control, Efficiency, Services) is a technique for identifying and solving problems that occur". PIECES analysis identifies the main problems of a system and provides solutions to these problems [9]. PIECES analysis consists of:

1. Performance (Performance or Reliability)

Performance problems occur when business tasks carried out do not reach the target. Performance is measured by the amount of production and response time. Performance can also be measured based on work volume, market share achieved, or company image.

2. Information

Information is a crucial commodity for end users. Evaluation of the ability of information systems in producing useful information needs to be done to respond to opportunities and deal with emerging problems. Lack of relevant information in making decisions is a situation that requires increased information.

3. Economy

Economics is the most common motivation for a project. The basic foundation for most managers is cost or rupiah. Economic issues and opportunities are related to cost issues.

4. Control (Control or Security) Controls are installed to improve system performance, prevent or detect system errors, ensure data security, information and requirements.

5. Efficiency

Efficiency involves how to produce output as much as possible with the smallest possible input.

6. Services

System service quality is said to be bad if the system does not produce accurate products, the system does not produce consistent products, the system is not easy to use and the system is not flexible.

\section{Performance}

Performance Analysis is the ability to complete business tasks quickly so that targets can be achieved immediately. Performance is measured by the amount of production and response time of a system.

Table 1. Performance Analysis Results

\begin{tabular}{|c|l|}
\hline Parameter & \multicolumn{1}{c|}{ Analysis results } \\
\hline Throughput & $\begin{array}{l}\text { Inputting data that is not yet effective and efficient, there are } \\
\text { errors when data collection of waqf data is not noticed. }\end{array}$ \\
\hline Response Time & $\begin{array}{l}\text { The time needed is quite long when submitting a representative } \\
\text { report on waqf land assets. }\end{array}$ \\
\hline
\end{tabular}

\section{Information}

Information is the most important commodity for an end user in a system in decision making. With a good information system it will produce useful information as a support in responding to problems and opportunities that exist. 
Table 2. Information Analysis Results

\begin{tabular}{|c|l|}
\hline Parameter & \multicolumn{1}{c|}{ Analysis results } \\
\hline Accurate & $\begin{array}{l}\text { Often found errors in the process of accurate location of waqf land } \\
\text { assets, as a result the information submitted to the head of KUA } \\
\text { and the community is still inaccurate. }\end{array}$ \\
\hline Relevant & $\begin{array}{l}\text { Presentation of data is less relevant so it needs a system that } \\
\text { makes it easy and can provide clear information. }\end{array}$ \\
\hline On time & $\begin{array}{l}\text { Time delay when submitting a waqf land asset report, resulting in } \\
\text { an obstacle when making a decision. }\end{array}$ \\
\hline
\end{tabular}

\section{Economy}

In the current system, it still requires costs, in terms of the economics of the system that is currently still costing not less every time will record data on waqf land assets, so that the current system is still less economical.

\section{Table 3. Economic Analysis Results}

\begin{tabular}{|c|l|}
\hline Parameter & \multicolumn{1}{|c|}{ Analysis results } \\
\hline Cost & $\begin{array}{l}\text { It still incurs economic, labor and time costs in checking and recording data on } \\
\text { waqf land assets because it records the available forms and other files in the } \\
\text { map. }\end{array}$ \\
\hline
\end{tabular}

\section{Control}

Control in the system is very necessary, which is used to improve system performance, prevent or detect misuse or system errors and to ensure the security of data and information.

\section{Table 4. Control Analysis Results}

\begin{tabular}{|c|l|}
\hline Parameter & \multicolumn{1}{|c|}{ Analysis results } \\
\hline System Control & $\begin{array}{l}\text { System control in filling out wakif, witness and nadzir registration } \\
\text { data and registration of waqf land assets, namely still using the } \\
\text { registration form so that it is still less effective. }\end{array}$ \\
\hline
\end{tabular}

\section{Efficiency}

Efficiency relates to how the available resources can be used as well and as economically as possible with the most minimum waste / cost.

Table 5. Efficiency Analysis Results

\begin{tabular}{|c|l|}
\hline Parameter & \multicolumn{1}{c|}{ Analysis results } \\
\hline $\begin{array}{c}\text { Cost } \\
\text { Resources }\end{array}$ & $\begin{array}{l}\text { Recording of paper forms used for recording data on waqf land assets and files } \\
\text { is too excessive. }\end{array}$ \\
\hline $\begin{array}{c}\text { Power } \\
\text { Resources }\end{array}$ & $\begin{array}{l}\text { The work done by PPAIW input into the system, while many data on waqf } \\
\text { assets must be inputted, as well as reports that are awaited too long. Therefore } \\
\text { it greatly slows down work. }\end{array}$ \\
\hline
\end{tabular}

\section{Service}

The services provided are very supportive in improving quality. Service is a factor that determines whether an institution / agency can achieve the objectives of policy formation or not. Because development is triggered by good service satisfaction. 


\section{Table 6. Service Analysis Results}

\begin{tabular}{|c|l|}
\hline Parameter & \multicolumn{1}{|c|}{ Analysis results } \\
\hline Service Process & $\begin{array}{l}\text { The services provided by PPAIW to Wakif, witnesses and } \\
\text { Nadzir are still lacking, because the system service process } \\
\text { that runs at this time has not made it easier for PPAIW to } \\
\text { result in frequent errors in data collection of member loan } \\
\text { applications. }\end{array}$ \\
\hline
\end{tabular}

\section{Implementation}

According to Putra, et all (23: 2018) "Implementation is a process to ensure the implementation of a policy and the achievement of the policy. Implementation is also intended to provide a means to make things and give practical results to others. "

In this study a system planning will be carried out to be implemented for the representation process at the Cikupa District Office of Religious Affairs using the PHP programming language and the Unified Modeling Language (UML).

\section{Results and Analysis}

\subsection{Current System Analysis}

\section{A. Registration for Waqf Land}

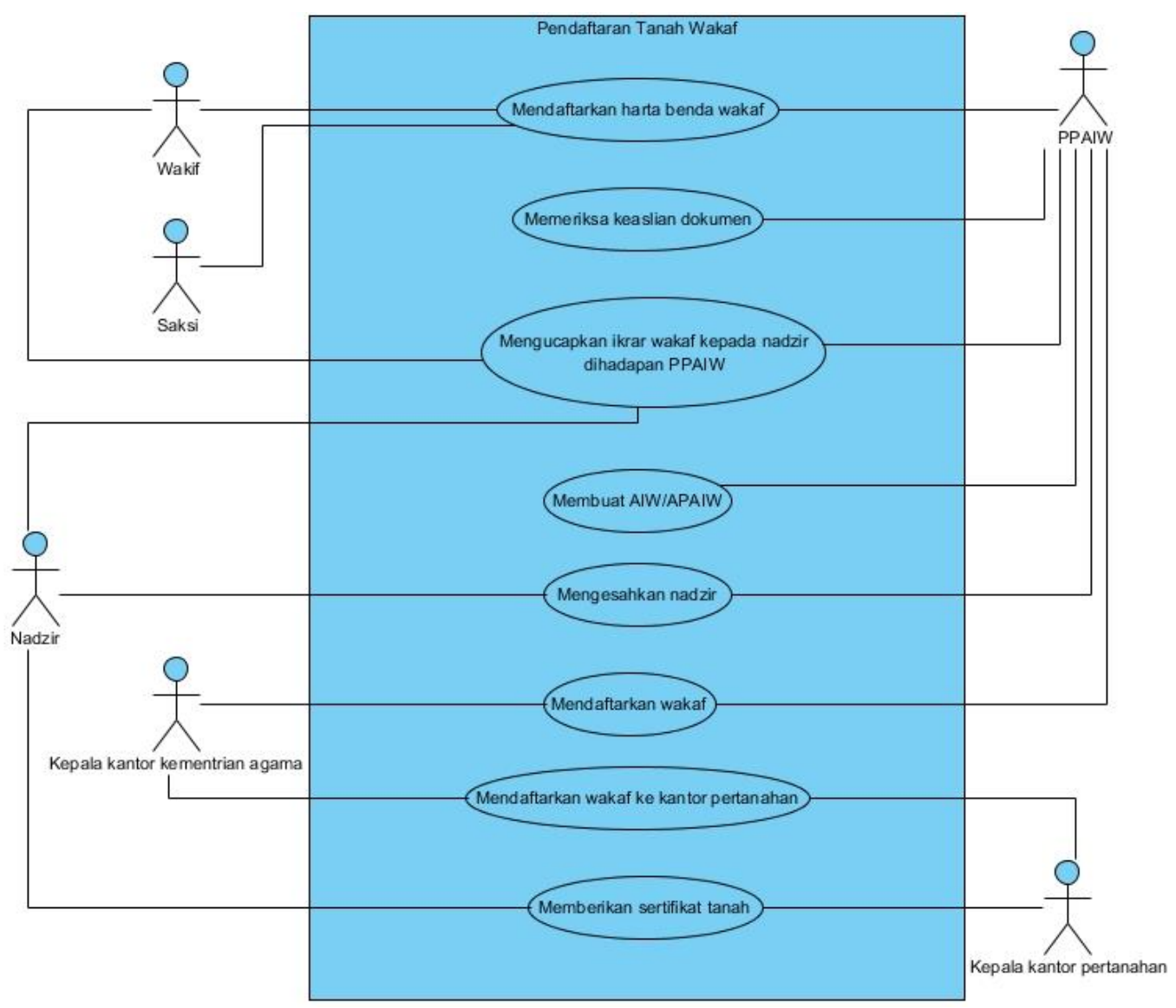

Figure 3. Use Case Diagram Registration for Waqf Land 
Based on figure 3 Use Case Diagram of the system of representation of waqf land assets that is currently running, there are:

1. One system, namely registration of waqf land.

2. Six actors who carry out activities, including Wakif, witnesses, Nadzir, PPAIW, Head of the Ministry of Religion Office, Head of the Land Office.

3. Six use case diagrams, including: Registering waqf property, checking the authenticity of documents, giving waqf vows to nadzir before PPAIW, making AIW / APAIW, authorizing nadzir, registering endowments, registering endowments to the land office, giving land certificates.

\subsection{Current System Analysis}

\section{A. Display of Main Page (Home)}

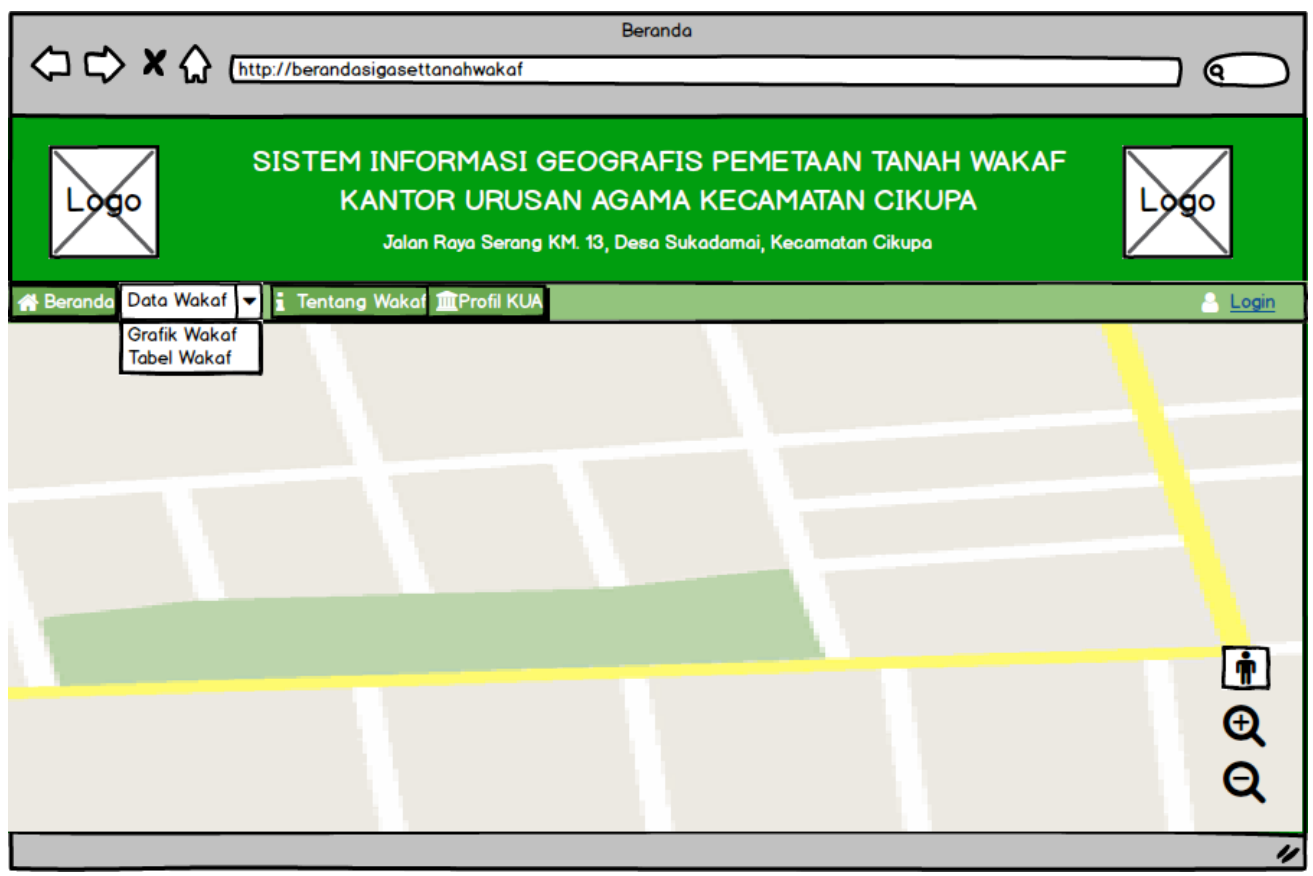

Figure 2. Display of Main Page (Home)

The user directly goes to the main page (homepage) without logging in first. On the main page image (home page) there are several icons such as: home page, waqf graph data, waqf table data, about waqf and KUA profile. On this page there is also a logo from the Ministry of Religion and logics of waqf. This main page provides a user interface that makes it easy for users to process viewing waqf land through digital maps available on the homepage. Then on this page there is a list of waqf tables and graphs that have been inputted by the admin.

\section{B. Wakaf Display of Waqf Land Register}




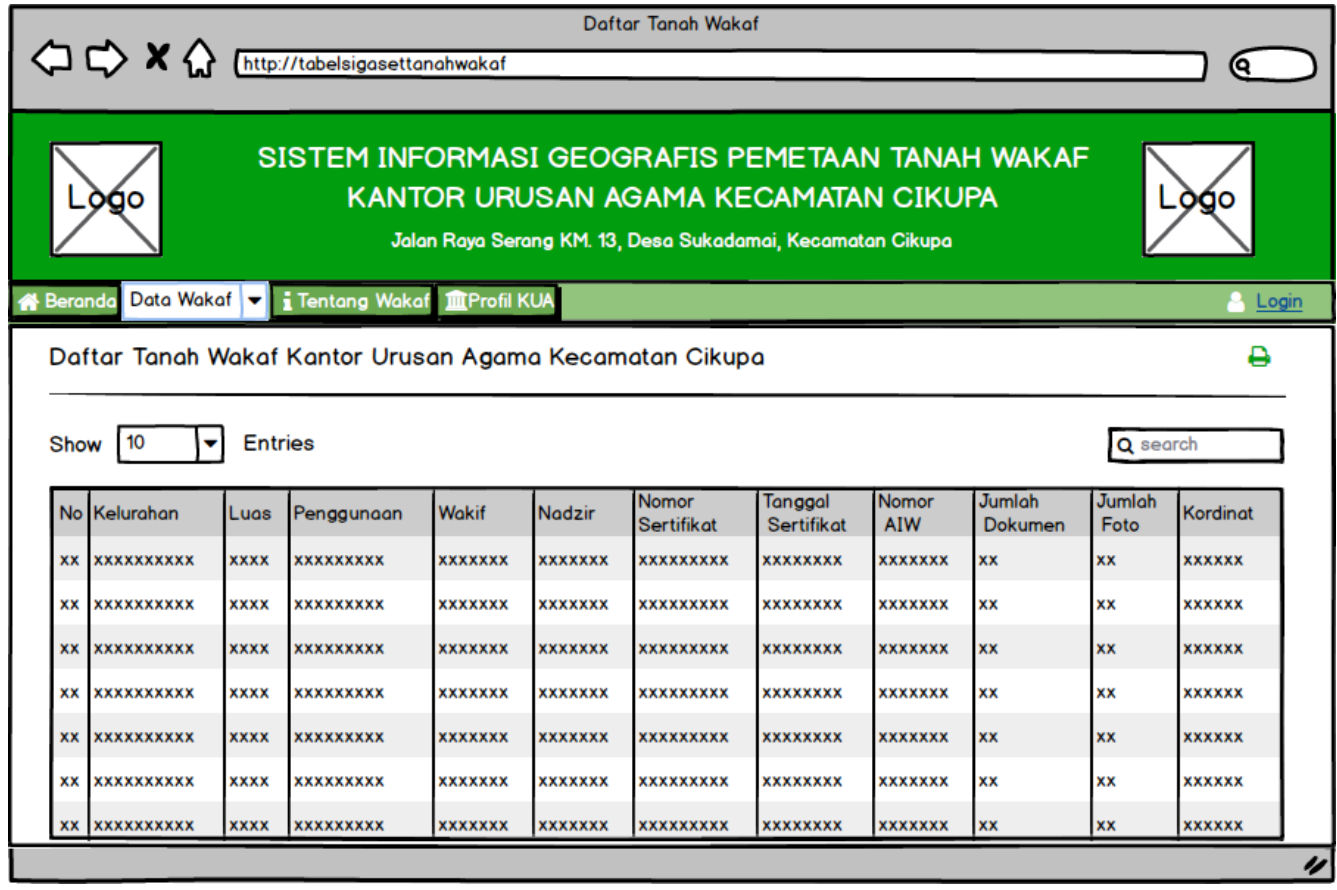

Figure 3. Display of Waqf Land Register

After the user presses the "Data Endowments" button on the home page, the user will enter the waqf land table display page in the form of a table that can be saved.

\section{Display Chart of Waqf Land}

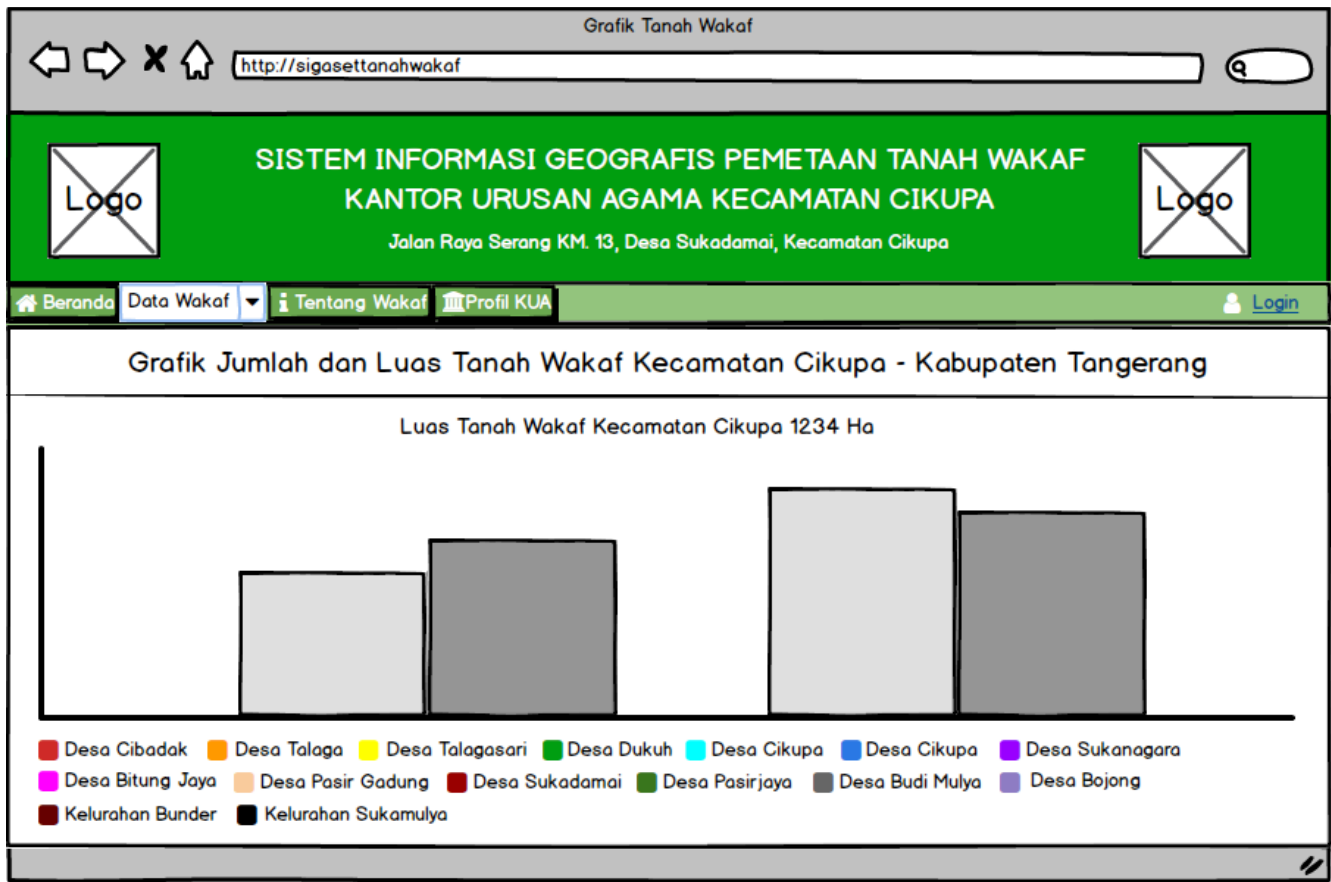

Figure 4. Display Chart of Waqf Land

In figure 4, the user can see the waqf land area in the form of graphs per village / kelurahan in the Cikupa District area

\section{Display of Waqf Location Data}




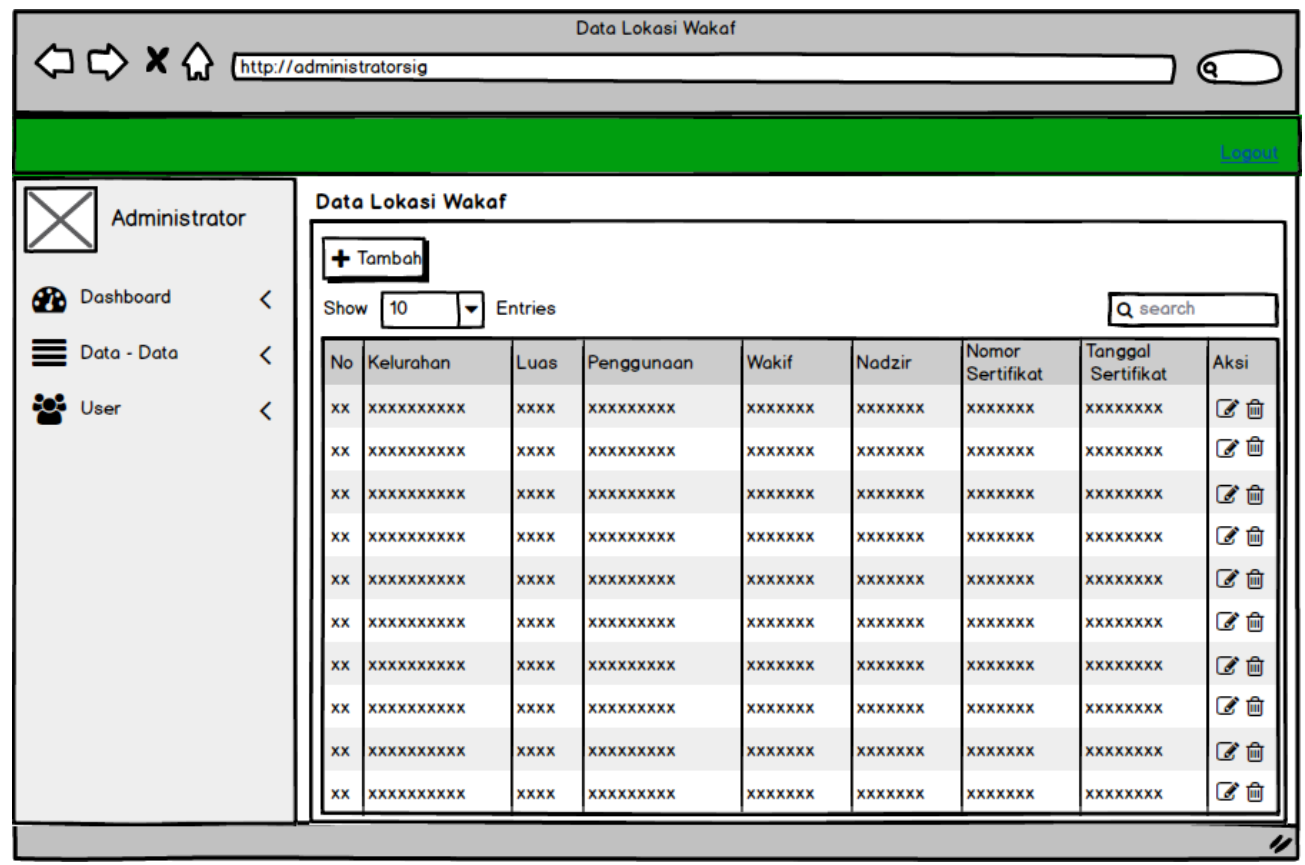

Figure 5. Display of Waqf Location Data

In this view the admin can search, edit, delete and add add data on waqf land.

\section{E. Display of Waqf Data Input}

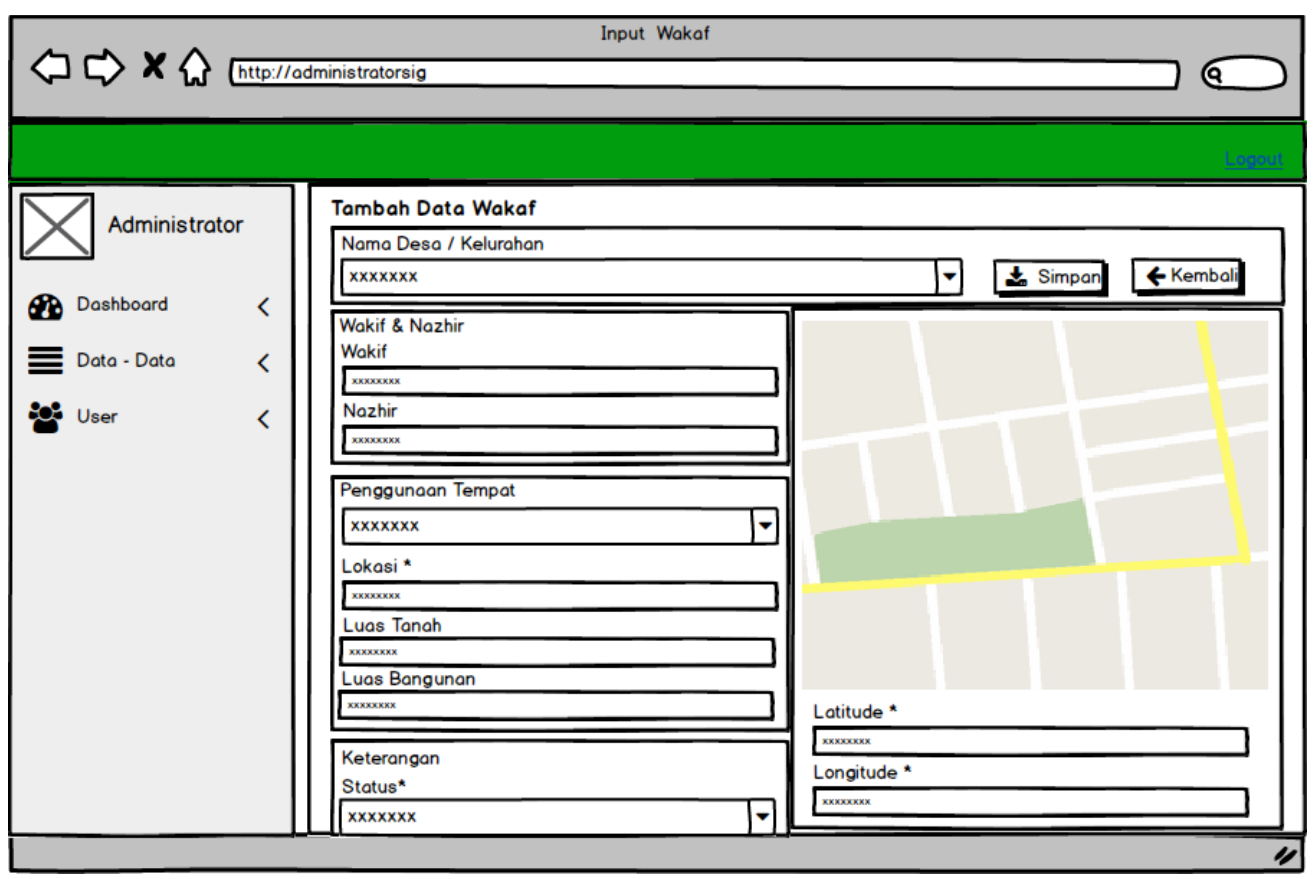

Figure 6. Display of Waqf Data Input

In this view the admin can add waqf land data in the form of village / kelurahan names, wakif, nazhir, use of place, location, land area, building area, status and can mark the location of waqf land through digital maps.

\section{Conclusion}

Based on the results of research conducted at the Office of Religious Affairs in Cikupa District, conclusions can be drawn as follows: 
1. The current system at the Cikupa District Religious Affairs Office is still not optimal. Control in the system is very necessary, which is used to improve system performance, prevent or detect misuse or system errors and to ensure the security of data and information. System control in filling out wakif, witness and nadzir registration data and registration of waqf land assets, namely still using the registration form so that it is still less effective.

2. The design of geographic information systems monitoring waqf land assets using php programming language, java script and MySql database. Navigation and interaction of the application system with the browser using the Google Maps API to display and describe information referring to the geographical location of waqf objects so that they can display the location of waqf assets accurately and quickly.

3. Processing of geographic information systems monitoring waqf land assets that can store, repair, renew, manage, manipulate, integrate, analyze and display data in a geographic-based information that has more flexible power than paper sheet sheets.

\section{References}

[1] Fahmi, Amiq and Edi Sugiarto. 2015. Application of Endowments Asset Management Geographic Information System. Semarang: Dian Nuswantoro University. Proceedings of the 2nd SNATIF 2015. ISBN: 978-602-1180-21-1.

[2] Fahmi, Amiq and Edi Sugiarto. 2016. Geographic Information System for Management and Monitoring of Distribution of Endowments Assets. Semarang: Dian Nuswantoro University. Techno.COM, Vol. 15, No. 4, November 2016: 327-334.

[3] Sutejo. 2016. UML Modeling of Geographical Information Systems for Traditional Markets in Pekanbaru City. Pekanbaru: Lancang Kuning University. Journal of Digital Information \& Communication Technology Zone, Volume 7, Number 2, November 2016: 89-99.

[4] Yuniarti, Ummi Athiyyah, Bambang Sudarsono and Arwan Putra Wijaya. 2014. Webbased Application of Geographical Information System for the Spread of Dengue Hemorrhagic Fever (Case Study: Kudus District). Semarang: Diponegoro University. Undip Geodetic Journal, Volume 3, Number 3, 2014, (ISSN: 2337-845X).

[5] Thoullah, C. K., Bilqisti, A., \& Alifiyanto, D. (2019). Designing a Geographic Information System (GIS) as a Web-Based Information Industry Apparatus in South Tangerang 6 Vocational School. STORIES, 55-67.

[6] Putra, A. S., Febriani, O. M., \& Bachry, B. (2018). Implementation of Genetic Fuzzy System to Identify Results of Motor Vehicle Stolen in Lampung Regional Police. Journal of Database Information \& Management Systems (SIMADA) Vol. 1 No. 1, 21-30.

[7] Azizah, N., Rahayu, S., \& Adhista, N. (2017). Designing SPG Employee Performance Assessment Information System Contract Status at PT. Softe Indonesia Uses Simple Additive Weighting (SAW) Method. Journal of SENSE Vol. 3 No. 2, 182 - 189.

[8] Son, D. W., \& Kadris. (2016). Geographic Information System Mapping Infrastructure Facilities of the Sungai Penuh City Department of Religion Based on the Web. TEKNOIF Journal. Vol. 4 No. October 2, 2016, 76-81. 
[9] Asbar, Yuli, and Mochamad Ari Saptari. 2017. "Analysis in Measuring Service Quality for Consumer Satisfaction Using the PIECES Method". Visionary \& Strategic Journal Vol. 6 Number 2, September 2017: 39-47.

[10] Law of the Republic of Indonesia Number 41 of 2004 concerning Endowments

[11] Roihan, A., Sunarya, P. A., \& Wijaya, C. (2018, August). Auto Tee Prototype as Tee Golf Automation in Golf Simulator Studio. In 2018 6th International Conference on Cyber and IT Service Management (CITSM) (pp. 1-5). IEEE. 